\title{
Comparison of morphological quantitative characteristics of the newly formed alveolar bone after the application of demineralized bone matrix and cortical bone allografts
}

\author{
Comparación de las Características Morfológicas Cuantitativas del Hueso Alveolar Recién Formado \\ Después de la Aplicación de Matriz ósea Desmineralizada y Aloinjertos de Hueso Cortical
}

Fernando José Dias $^{1,2}$; Alain Arias ${ }^{1,2,3}$; Eduardo Borie ${ }^{1,2}$; Maria Florencia Lezcano²; Manuel Arellano -Villalón ${ }^{1,2}$ \& Ramón Fuentes ${ }^{1,2}$

DIAS, F. J.; ARIAS, A.; BORIE, E.; LEZCANO, M. F.; ARELlANO -VILLALÓN, M. \& FUENTES, R. Comparison of morphological quantitative characteristics of the newly formed alveolar bone after the application of demineralized bone matrix and cortical bone allografts. Int. J. Morphol., 37(4):1509-1516, 2019.

SUMMARY: The allografts were used to obtain sufficient alveolar bone tissue for proper dental implant placement. The objective of the present study was to evaluate the morphological and quantitative characteristics (cellular and collagen densities) of the newly formed alveolar bone with the application of cortical bone (CB) and demineralized bone matrix (DBM) allografts. Six samples of alveolar bone tissue from 5 patients $(50 \pm 6.3$ years) were obtained after 6 months of application of the allografts and immediately before the placement of the dental implants. The samples were fixed (buffered formaldehyde, pH7.2), decalcified (EDTA $10 \%$ ) and histologically processed (HE and Picro-Sirius) for histologic analysis. Morphological analysis revealed presence of osteocytes and trabeculae in neoformed bone tissue near the allografts and absence of inflammatory and allergic cells; the remnants of CB were located mainly in the periphery of the bone tissue and the remnants of DBM were more incorporated into the tissue. Osteogenitor cells were observed around the remaining material. The cell density was not modified in newly formed bone tissue with the application of both allografts as compared to mature bone tissue. The density of the type I and III collagens present in the osteoids interspersed with the remainder of the materials showed a tendency to increase in the samples treated with DBM. It was concluded that by the histological characteristics observed both grafts were biocompatible, however the bone treated with DBM presented better incorporation and a tendency of increase of the collagen content in the remnant region of the allografts.

KEY WORDS: New bone formation; Biomaterials; Bone Graft; Quantitative Analysis.

\section{INTRODUCTION}

Dental implants are best modern dentistry treatment for replacing missing teeth. To achieve optimum results with dental implants, adequate and sufficient bone should be available to support and stabilize them (Motamedian et al., 2016; Kubota et al., 2017).

Bone tissue transplantation and the use of biocompatible grafts are options to increase or maintain the volume of bone tissue needed in the area of alveolar bone that will receive a dental implant (Grageda, 2004).

Autograft is considered the "gold standard" graft, in which bone tissue from the same patient is used, however it requires a sensitive surgical technique (Yunes et al., 2015), besides not being an endless source of material and associated the morbidity that can cause the patient, such as pain, fracture, regeneration problems among others (Bhatt \& Rozental, 2012). The allografts are processed materials coming from the same species in which the graft will be applied. Due to this fact, the risk of having immune responses is lower. They are usually used in patients with no possibility of using autograft (Kremenetzky et al., 2006).

Among the allografts we can mention the demineralized bone matrix and the particulate cortical bone as clinical options for the bone neoformation necessary for the placement of a dental implant (Aichelmann-Reidy \& Reynolds, 2008; Shalash et al., 2013; Campana et al., 2014;

\footnotetext{
${ }^{1}$ Department of Integral Adults Dentistry, Dental School, Universidad de La Frontera, Temuco, Chile.

${ }^{2}$ Research Centre for Dental Sciences (CICO), Dental School, Universidad de La Frontera, Temuco, Chile.

${ }^{3}$ Universidad Adventista de Chile, Chillán, Chile.
} 
DIAS, F. J.; ARIAS, A.; BORIE, E.; LEZCANO, M. F.; ARELLANO - VILLALÓN, M. \& FUENTES, R. Comparison of morphological quantitative characteristics of the newly formed alveolar bone after the application of demineralized bone matrix and cortical bone allografts. Int. J. Morphol., 37(4):1509-1516, 2019.

Ali et al., 2014; Bencharit et al., 2015; Pensak et al., 2015; Motamedian et al.; Kubota et al.; Majoor et al., 2017; Huang et al., 2017).

DBM is a type of refined allograft in which the material is withdrawn its mineral phase so that it has a greater biocompatibility and reduces the probability of transmitting some disease. DBM facilitates osteoinduction, promoting the appearance of growth factors and stimulating the induction of mesenchymal cells, differentiating into osteogenic cells; this process is of great importance to repair bone defects (Bhatt \& Rozental). The DBM is a composite material by collagen matrix, non-collagen proteins and growth factors (Gazdag et al., 1995; Gruskin et al., 2012).

Particulated cortical bone allograft is a type of biological bone substitute of human origin. Currently cortical bone allografts are the most widely used of long bone defects (Huang et al.). An advantage of this type of graft is the proximity to the constituent elements and the architecture of the bone tissue, as disadvantage is the potential transmission of diseases (Ali et al.).

This case-series study aimed analyze the morphologic and histologic quantitative characteristics of alveolar bone that received demineralized bone matrix (DBM) or Cortical Bone $(\mathrm{CB})$ of patients with atrophic mandibular ridge.

\section{MATERIAL AND METHOD}

Participants. The present case series study was performed in five male patients $(50 \pm 6.3$ years old) without systemic pathologies attending to dental private practice in Temuco, Chile. From them were obtained five mandibular sites that were evaluated through clinical examination and histological analysis. These patients required bone substitute material before the placement of endo-osseous dental implants in the sites mentioned. In the six mandibular sites of five volunteers was observed alveolar ridge thickness of $3.0 \mathrm{~mm}$ or less. The patients received a detailed explanation of the proposed treatment, agreed and authorized the histological analysis of the bone samples and publication of the results through an informed consent.

Bone Grafts Application Procedure. The application of bone grafts followed these steps: a mucoperiosteal flap was performed in the area and moved towards vestibular. Small holes were made in the alveolar bone with a round carbide bur (012) to activate blood flow and to place the bone substitute material. Finally, periosteum was cut in the deepest internal area of the flap to increase length and then sutured.
The bone substitutes used in this study were a Cortical Bone allograft (Puros ${ }^{\circledR}$, Zimmer Biomet, Germany) and Demineralized Bone Matrix present in putty DBM (DynaGraft·D ${ }^{\mathrm{TM}}$ putty, Keystone Dental, USA).

Sample collection and histological processing. After 6 months of the bone grafts application the dental implants were placed. The six bone samples histologically analyzed in this study were obtained in the alveolar preparation phase for implant placement with trephine drill $(3 \mathrm{~mm}$, external diameter), thus was not caused additional damage to the patient.

The bone samples were fixed in buffered $4 \%$ formalin and stored at $4{ }^{\circ} \mathrm{C}$ for $\sim 4$ weeks. Subsequently, samples were rinsed with saline solution $(\mathrm{NaOH}, 0.9 \%)$ and decalcified using EDTA solution $\left(10 \% ; \mathrm{pH} 7.2 ; 22-24^{\circ} \mathrm{C}\right)$; the EDTA solution was changed every 3 days for a period of 2 months. The samples were cut longitudinally with a Leica@ RM2255 microtome with $3 \mu \mathrm{m}$ thickness. The hematoxylin-eosin (HE) and Sirius red stainings were performed, the stained microscope slides were analyzed with an optical microscope Leica ${ }^{\circledR}$ DM750 and camera Leica® ${ }^{\circledR}$ ICC50 HD, at a final magnification of X100 and X400.

Morphological and Quantitative Analyzes.The qualitative morphological analysis was performed on the images stained with HE, with X100 and X400 of magnification.

Quantitative analysis of cell density was also performed on HE stained photomicrographs. Using the ImageJ software (1.48s, Free, NIH - USA) the osteocytes were counted in the bone tissue neoformed with the "Cell Counter" tool, to normalize this data, the area of neoformed bone tissue was measured and the cell value was divided by this area resulting in cell density $\left(\right.$ cells $\left./ \mathrm{mm}^{2}\right)$.

For the analysis of collagen densities, ImageJ software (1.48s, Free, NIH - USA) was also used, considering only the areas of remaining graft and analyzing the content of collagens type I and III that were present interspersed with the materials. The previously described pixel count method was used (Dias et al., 2013; Cury et al., 2016; Fuentes et al., 2017). The areas of this material remaining in the samples were initially defined (Fig. 1A) them the other areas were erased (Fig. 1B), the color channels were divided using the tool "Color> Split channels", considering only red (type I collagen) and green (type III collagen). Finally, each image was transformed into binary images (Fig. 1C, black and white). Using the "Area calculator" tool, the black areas were obtained. The obtained value of each collagen areas were divided by the remaining area of the remaining material obtaining the collagen densities (\%). 

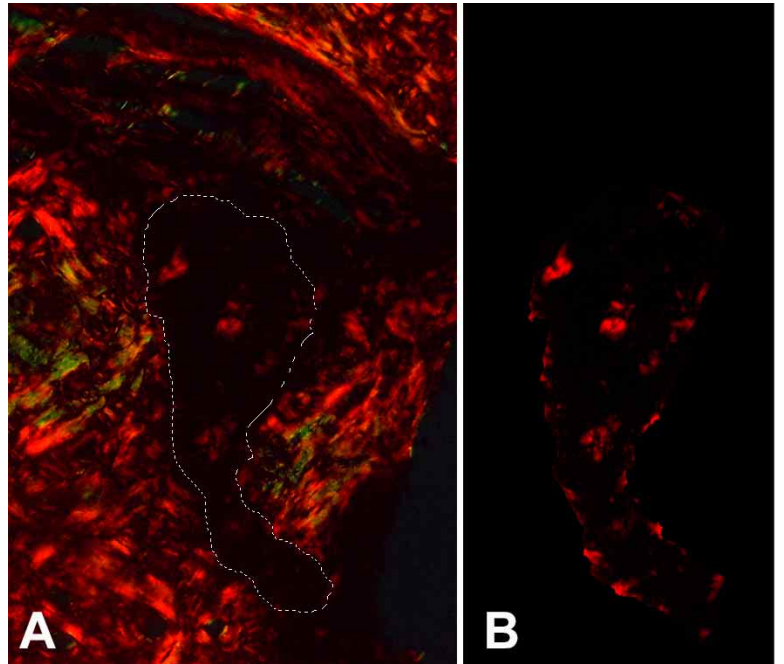

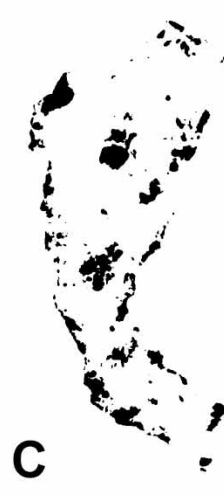

Fig. 1. Analysis of the density of collagen. (A) Samples stained with Picro-Sirius under light polarized with the delimitation of the remainder area of the allograft. (B) Individualized collagen content of the area corresponding only to the allograft.

(C) Collagen content in binary for analysis to ImageJ software.

Statistical analysis. SigmaPlot 12.0 software (Systat software Inc. San Jose, CA, USA) was used for the statistical analysis. The Shapiro-Wilk test was used to determine the normality of the data. For the data with normal distribution, we used One-Way ANOVA $(p=0.05)$, followed by the Holm - Sidak post hoc test. Data were presented as mean \pm standard deviation. For the data whose distribution was not normal, the Kruskal-Wallis test and Dunn 's post hoc test were used. Data were presented with medians, low $(25 \%)$ and high $(75 \%)$.

\section{RESULTS}

Morphological analysis. The alveolar bone samples obtained from the patients who received the "Cortical Bone Graft" presented remnants of the material mainly in the peripheral area of the tissue (Fig. 2A and Fig. 2B). The bone tissue formed around and the osteoid interspersed with the remaining material and the juxtaposition of both are suggestive of biocompatibility and osseointegration (Fig. 2A). No inflammatory and allergic cells were noted in these samples. In the osteoid interspersed to the material it was possible to notice the presence of osteocytes in trabeculae. Around the remaining material, cellular linear formations suggestive of the presence of osteoblasts were observed (Fig. 2B).

The bone tissue samples from the patients who received "DBM" also presented remnant of the material after
6 months of its application, however, a more uniform distribution was observed throughout the sample area of ??the bone tissue, not being present only in the periphery (Fig. 2C). Again, osteintegration characteristics of the material applied with the alveolar bone present in the samples were observed. It was possible to detect bone tissue surrounding the material, osteoid formations juxtaposed and interspersed with the presence of osteocytes, as well as the linear cell formation around the material, suggestive of osteoblasts (Fig. 2D).

Cellular Density. Analysis of the neoformed bone tissue of patients receiving CB (CB NB) showed a cell density of 631.5 (low - 410.6; high - $1167 \mathrm{cel} / \mathrm{mm}^{2}$ ). The application of DBM (DBM NB) to the alveolar bone resulted in a neoplasm of osteoid with cell density of 312.6 (low 216.1; high - $520.2 \mathrm{cel} / \mathrm{mm}^{2}$ ) (Fig. 2E). Thus, the cellular density of the osteoid of the patients who received CB was significantly higher in comparison to patients who received DBM $(\mathrm{P}=0.019)$. However, the evaluation of the cellular densities in the mature bone tissue of the same patients $(\mathrm{CB}$ MB - med - 712.8; low - 460.7; high $-1219.8 \mathrm{cel} / \mathrm{mm}^{2}$ and DBM MB - med - 430.5; low - 259.6; high - $520.7 \mathrm{cel} / \mathrm{mm}^{2}$ ) did not show significant differences regarding the areas of neoformed bone tissue.

Density of collagen in the osteoid interspersed with the remaining material. Under polarized light analysis, two types of collagen type I (red) and type III (green) collagen were present in the osteoid formed between the alveolar bone samples of patients receiving CB (Fig. 3A and Fig. 3B) and DBM (Fig. 3C and Fig. 3D). In both cases the proportion of type I collagen was higher than type III.

The analysis of the density of the type I collagen in osteoids among the remaining material, even with different values, did not reveal significant differences between the applications of CB (Med - 8.2; low - 5.6; high - $15.1 \%$ ) and DBM (Med- 18.7; low - 7.9; high - $30 \%$ ) (Fig. 3E).

The density of type III collagen in the osteoid formed between the remaining material presented similar characteristics to type I collagen. Thus, there was no difference associated with the material used (CB - $0.59 \pm$ $0.69 \%$ and DBM $-1.67 \pm 1.89 \%$ ), even with larger values observed in the patients who received the DBM application (Fig. 3F). 

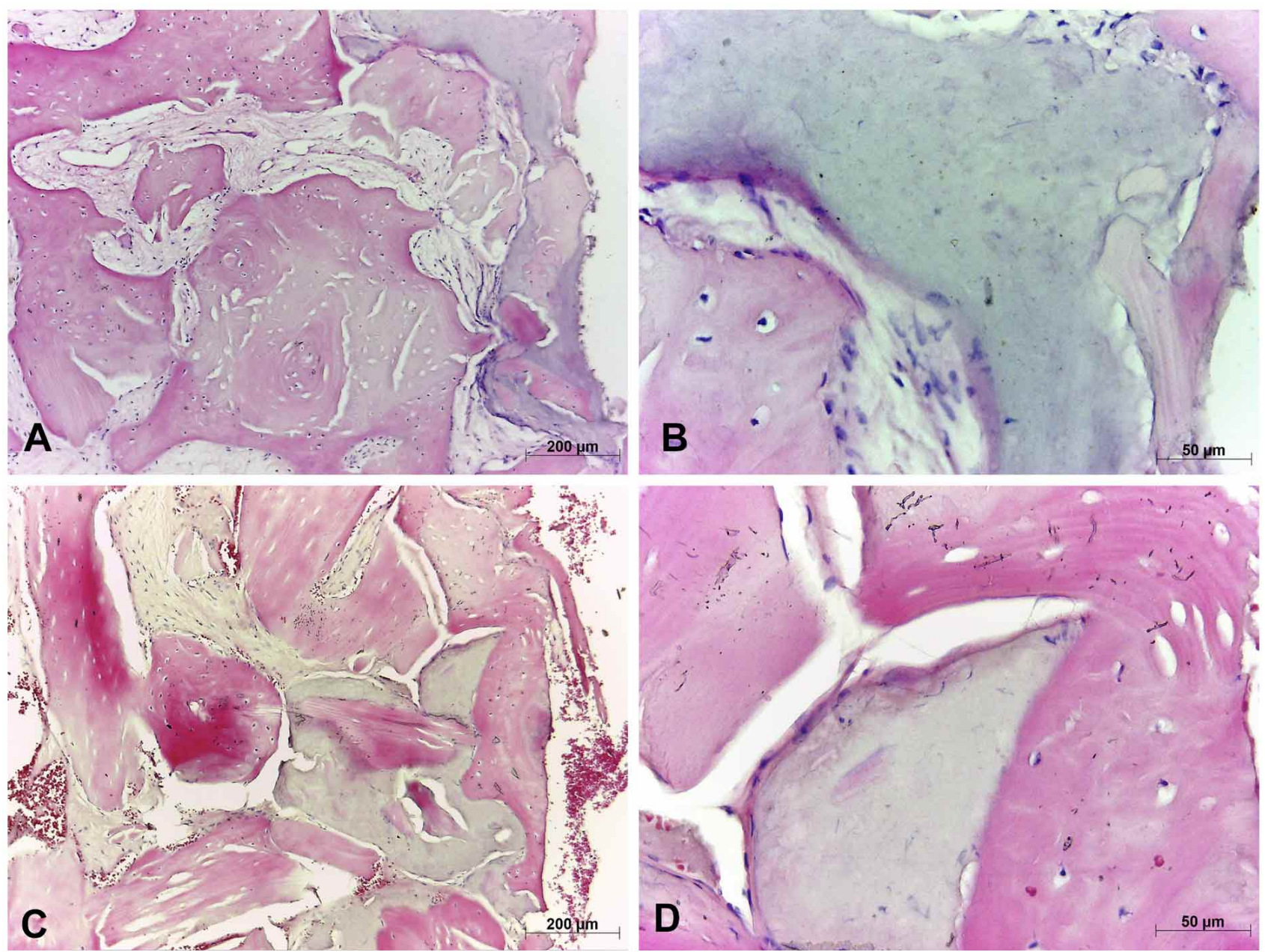

\section{Bone Cellular Density}

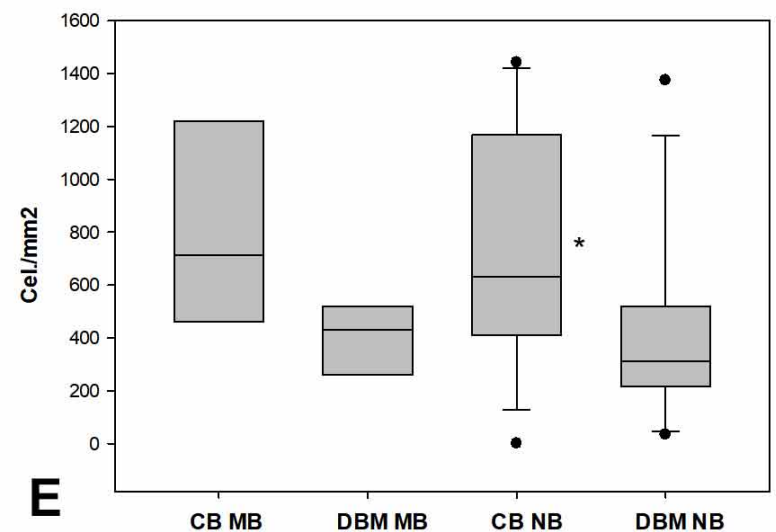

Fig. 2. Qualitative Morphological Analysis. (A) Cortical Bone Neoformed bone tissue juxtaposed to the remnant of the material in the peripheral region (X100). (B) Cortical Bone - A linear formation suggestive of osteoblasts around the remainder of the material (X400). (C) DBM - Bone formation around the remaining graft material (X100). (D) DBM - Linear formation suggestive of osteoblasts around the remaining material (X400). (E) Density of osteocytes Chart. Comparisons between mature bone tissue of patients with application of $\mathrm{CB}$ (CB MB) and DBM (MB DBM), and neoformed bone with $\mathrm{CB}(\mathrm{CB} \mathrm{NB})$ and $\mathrm{DBM}(\mathrm{DBM}-\mathrm{NB})$. There was only difference between $\mathrm{CB}$ NB and DBM NB ( $\mathrm{p}=$ $0.019)$.

\section{DISCUSSION}

The present study analyzed the morphological and quantitative histological characteristics of the newly formed

alveolar bone after the application of two allografts Cortical Bone and Demineralized Bone Matrix prior to the placement of intraosseous dental implants in patients. Previous studies have shown positive results with the use of these grafts by different methods of analysis (Aichelmann-Reidy \& 

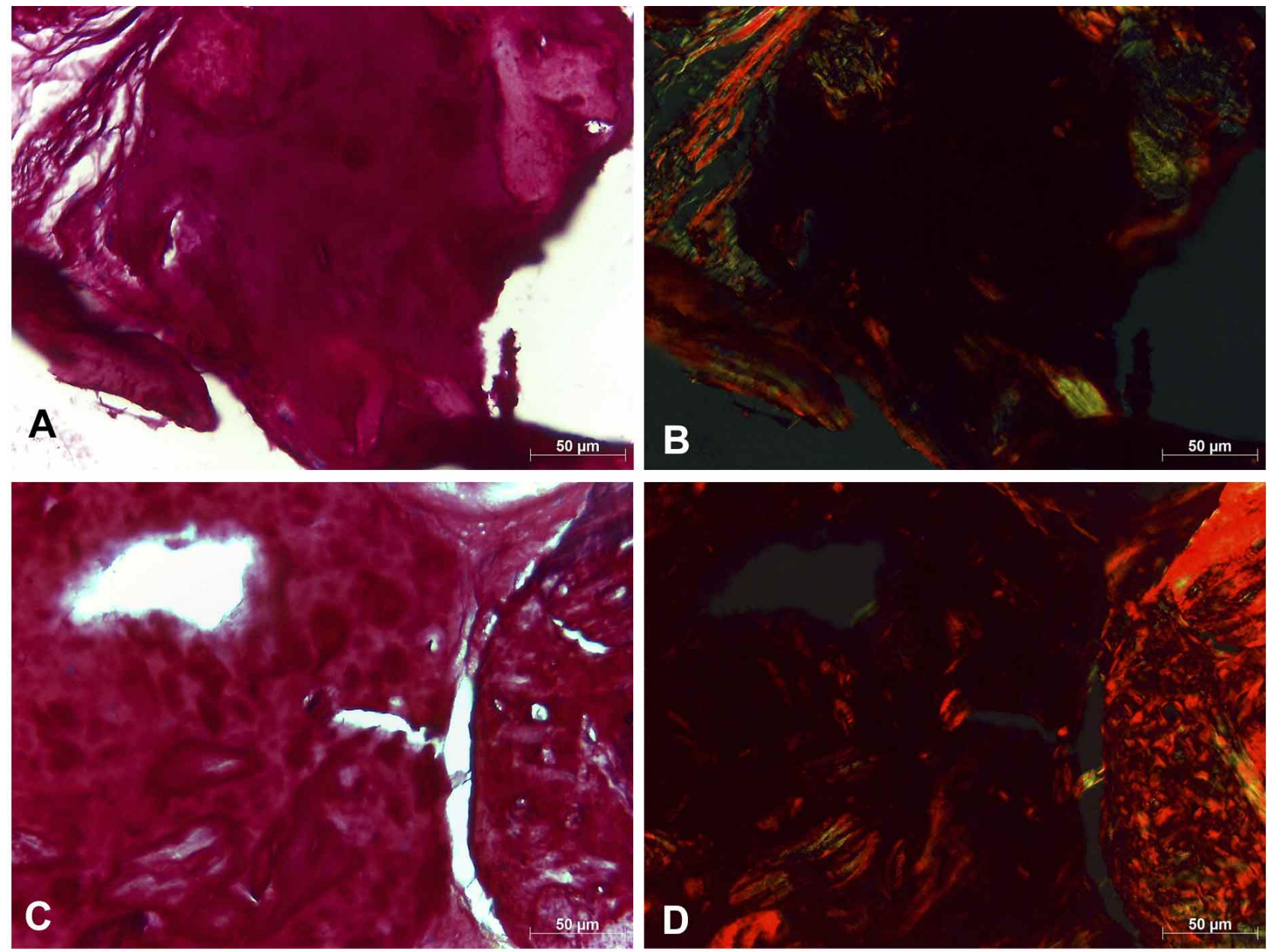

Collagen I Density

Collagen III Density
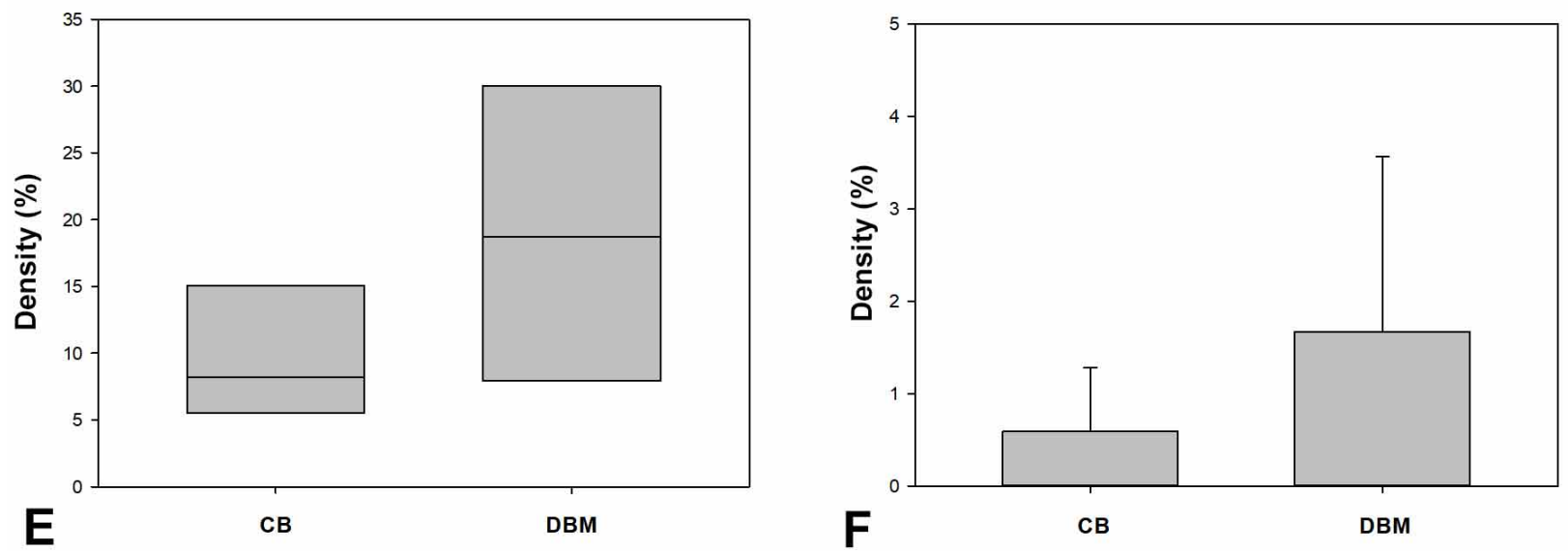

Fig. 3. Analysis of the Density of Collagens I and III, Picro-Sirius staining. (A) Cortical Bone - Remnant of CB under normal light (X400). (B) Cortical Bone - Remnant of CB under polarized light, the presence of collagens type I (red) and type III (green) (X400) is noted. (C) DBM - Remaining DBM under normal light (X400). (D) DBM - Remaining DBM under polarized light, the presence of type I (red) and type III (green) collagens (X400) is noted. (E) Type I collagen density Chart - No significant difference was observed between CB and DBM ( $>>0.05)$. (F) Type III collagen density chart - No significant difference was observed between CB and DBM $(\mathrm{p}>0.05)$. 
DIAS, F. J.; ARIAS, A.; BORIE, E.; LEZCANO, M. F.; ARELLANO - VILLALÓN, M. \& FUENTES, R. Comparison of morphological quantitative characteristics of the newly formed alveolar bone after the application of demineralized bone matrix and cortical bone allografts. Int. J. Morphol., 37(4):1509-1516, 2019.

Reynolds; Shalash et al.; Ali et al.; Campana et al.; Bencharit et al.; Pensak et al.; Motamedian et al.; Kubota et al.; Majoor et al.; Huang et al.). Kaya et al. (2009) revealed improvement of clinical parameters in hard and soft periodontal tissues with the use of different types of DBM, suggesting that the histological analysis was necessary to evaluate the regenerative potential of this type of graft in human bone defects.

In the histological analysis of the bone tissue after 6 months of application of the materials, trabeculae containing osteocytes were observed in the areas of neoformed bone tissue close to the remnants of both allografts. In addition, linearly shaped cell structures around the remnant material suggestive of osteoblasts were noted. No cells suggestive of inflammatory processes and hypersensitivity were observed.

Reports from previous studies revealed similar results in the use of CB (Deluiz et al., 2016) and DBM (Kadkhodazadeh et al., 2009). The presence of trabecular formations, presence of osteocytes and activity of osteoblastic cells. These characteristics indicate a good incorporation of the grafts (Deluiz et al.). The presence of inflammatory cells after 1-2 weeks in the use of DBM reported by (Kadkhodazadeh et al.) that differs from our results, may be due to the different periods analyzed.

The main morphological difference between $\mathrm{CB}$ and DBM applications was the location of the remnants of the materials. CB remains were present mainly in the periphery of the newly formed bone, and the remainder of DBM was more intermixed with neroformed alveolar bone tissue. These data suggest a better osseointegration (Bhatt \& Rozental) of the DBM compared to CB. Other clinical studies have also reported the presence of allograft remnants after 6 months of application (Shalash et al.; Motamedian et al.).

This difference in the incorporation of the applied grafts may be due to the different characteristics of both grafts with regard to osteoconduction and osteoinduction. The CB allograft presents a favorable architecture for neoformation of bone tissue, thus characterized as an osteoconductive biomaterial (Müller et al., 2013; Ali et al.; Campana et al.). DBM in addition to presenting osteocoduction also presents osteoinductive characteristics for the preservation of the organic matrix, which can often contain growth factors that play a fundamental role in the formation of extracellular matrix, proliferation and cell migration that directly induce the formation of bone tissue (Kadkhodazadeh et al.; Bencharit et al.; Pensak et al.; Jamjoom \& Cohen, 2015). Growth factors that may be present in DBM are bone morphogenetic proteins (BMP), transforming growth factor-b (TGF-b), fibroblast growth factor (FGF), insulin-like growth factor (IGF), vascular endothelial growth factor (VEGF) (Kaya et al.; Kadkhodazadeh et al.; Campana et al.; Jamjoom \& Cohen; Bencharit et al.; Pensak et al.).

In the analysis of the collagen components by polarized light microscopy, it was possible to observe that in the application of both BC and DBM the presence of osteoid formations interspersed with the remaining material composed of collagen, which was mainly type I, the main constituent of the organic portion of bone tissue (Shahar \& Weiner, 2018). The type III collagen was also present in these formations, however to a lesser extent. A previous study of our research group reported the formation of bone tissue with composition from two types of collagen when DBM putty was used for bone neoformation (Fuentes et al., 2017).

Quantitative analysis showed higher cell density in the neoformed bone tissue when $\mathrm{CB}$ was applied in comparison to DBM. However, similar values were observed in regions of mature bone from the same patients. These data suggest that differences in cell densities noted are related more to differences in tissue characteristics between patients than through application of materials. In addition, the grafting materials applied were not able to alter this characteristic of the neoformed bone tissue. Histological studies reported the presence of osteocytes in areas of neoformed bone with the application of CB and DBM allografts (Kadkhodazadeh et al.; Deluiz et al.). However, none of these studies evaluated the cell density of osteocytes in this area of newly formed tissue.

The densities of the types I and III collagens present in the osteoid formations interspersed with the remnants of the materials did not show significant differences, although higher values were observed when DBM was applied to both types of collagen compared to CB. This tendency, unconfirmed statistically, of higher collagen densities in the bone samples of patients who received the DBM application may be associated with their composition, which is mainly composed of collagen matrix, especially type I (Campana et al.; Pensak et al.; Liu et al., 2017). Our previous study with DBM putty application (Fuentes et al.), revealed results similar to the present study, in which we also noticed higher values of density of collagens type I and III in the samples of neoformed bone tissue of patients who received DBM, however without significant differences.

An ideal bone substitute should be biocompatible, do not evoke adverse inflammatory effects, with osteocodutive, osteoinductive characteristics, be reabsorbable, readily available and reasonably cost (Campana et al.) that integrates with tissues (Motamedian et al.). 
Although some differences were observed between the results obtained, the characteristics analyzed in the present study suggest that both allografts (CB and DBM) complied with the suggested precepts.

Among the limitations of the study, we can mention the small number of patients and the lack of homogeneity of the samples, even taking care to choose patients without systemic diseases or other alterations. We justify the small number and differences mentioned above of the samples due to the difficulty of obtaining bone tissue samples with the characteristics necessary for the present study.

Considering the limitations of the study, the data analyzed allow us to conclude that the allografts applied were biocompatible because they resulted in a new bone formation with presence of osteocytes, osteogenitor cells, absence of inflammatory and allergic components and formations composed mainly of type I collagen in the materials remaining. The materials were not able to modify the cellular density of newly formed bone tissue when compared to mature bone tissue. DBM presented better osseointegration and a tendency, not statistically confirmed, to increase collagen densities (type I and III). Future studies with a greater number of patients and incorporating different techniques of analysis may help to clarify and improve the understanding of the results obtained in the present study.

DIAS, F. J.; ARIAS, A.; BORIE, E.; LEZCANO, M. F.; ARELLANO - VILLALÓN, M. \& FUENTES, R. Comparación de las características morfológicas cuantitativas del hueso alveolar recién formado después de la aplicación de matriz ósea desmineralizada y aloinjertos de hueso cortical. Int. J. Morphol., 37(4):1509-1516, 2019.

RESUMEN: Los aloinjertos son utilizados para obtener tejido óseo alveolar apropiado para la colocación correcta del implante dental. El objetivo de este trabajo fue evaluar las características morfológicas y cuantitativas (densidades celulares y de colágeno) del hueso alveolar recién formado con la aplicación de aloinjertos de hueso cortical (CB) y matriz desmineralizada de hueso (DBM). Seis muestras de tejido óseo alveolar fueron obtenidas de 5 pacientes ( $50 \pm 6,3$ años) después de 6 meses de aplicación de los aloinjertos e inmediatamente antes de la colocación de los implantes dentales. Las muestras fueron fijadas (formaldehído tamponado, $\mathrm{pH} 7,2$ ), descalcificadas (EDTA al 10\%) y procesadas histológicamente (HE y Picro-Sirius) para el análisis histológico. El análisis morfológico reveló la presencia de osteocitos y trabéculas en el tejido óseo neoformado cerca de los aloinjertos y la ausencia de células inflamatorias y alérgicas; los remanentes de CB se ubicaron principalmente en la periferia del tejido óseo y los remanentes de DBM se incorporaron más en el tejido. Se observaron células osteogenitoras alrededor del material restante. La densidad celular no se modificó en el tejido óseo recién formado con la aplicación de ambos aloinjertos en comparación con el tejido óseo maduro. La densidad de los colágenos de tipo I y III presentes en los osteoides intercalados con el resto de los materiales mostró una tendencia a aumentar en las muestras tratadas con DBM. Se concluyó que, debido a las características histológicas observadas, ambos injertos fueron biocompatibles, sin embargo, el hueso tratado con DBM presentó una mejor incorporación y una tendencia al aumento del contenido de colágeno en la región remanente de los aloinjertos.

PALABRAS CLAVE: Formación de hueso nuevo; Biomateriales; Injerto óseo; Análisis cuantitativo.

\section{REFERENCES}

Aichelmann-Reidy, M. E. \& Reynolds, M. A. Predictability of clinical outcomes following regenerative therapy in intrabony defects. $J$. Periodontol., 79(3):387-93, 2008.

Ali, S. A.; Karthigeyan, S.; Deivanai, M. \& Kumar, A. Implant rehabilitation for atrophic maxilla: a review. J. Indian Prosthodont. Soc., 14(3):196207, 2014.

Bencharit, S.; Byrd, W. C. \& Hosseini, B. Immediate placement of a poroustantalum, trabecular metal-enhanced titanium dental implant with demineralized bone matrix into a socket with deficient buccal bone: A clinical report. J. Prosthet. Dent., 113(4):262-9, 2015.

Bhatt, R. A. \& Rozental, T. D. Bone graft substitutes. Hand Clin., 28(4):45768, 2012.

Campana, V.; Milano, G.; Pagano, E.; Barba, M.; Cicione, C.; Salonna, G.; Lattanzi, W. \& Logroscino, G. Bone substitutes in orthopaedic surgery: from basic science to clinical practice. J. Mater. Sci. Mater. Medd., 25(10):2445-61, 2014.

Cury, D. P.; Dias, F. J.; Miglino, M. A. \& Watanabe, I. S. Structural and ultrastructural characteristics of bone-tendon junction of the calcaneal tendon of adult and elderly wistar rats. PLoS One, 11(4):e0153568, 2016.

Deluiz, D.; Oliveira, L. S.; Fletcher, P.; Pires, F. R.; Tinoco, J. M. \& Tinoco, E. M. B. Histologic and tomographic findings of bone block allografts in a 4 years follow-up: a case series. Braz. Dent. J., 27(6):775-80, 2016.

Dias, F. J.; Issa, J. P. M.; Iyomasa, M. M.; Coutinho-Netto, J.; Calzzani, R. A. J.; Iyomasa, D. M.; Sousa, L. G.; de Almeida, S. R. Y.; Cury, D. P. \& Watanabe, I. S. Application of a low-level laser therapy and the purified protein from natural latex (Hevea brasiliensis) in the controlled crush injury of the sciatic nerve of rats: a morphological, quantitative, and ultrastructural study. Biomed Res. Int., 2013:597863, 2013.

Fuentes, R.; Saravia, D.; Arias, A.; Prieto, R. \& Dias, F. Mandibular dental implant placement using demineralized bone matrix (DBM). Biomed. Res. (India), 28(6):2656-60, 2017.

Gazdag, A. R.; Lane, J. M.; Glaser, D. \& Forster, R. A. Alternatives to autogenous bone graft: efficacy and indications. J. Am. Acad. Orthop. Surg., 3(1):1-8, 1995 .

Grageda, E. Platelet-rich plasma and bone graft materials: a review and a standardized research protocol. Implant Dent., 13(4):301-9, 2004.

Gruskin, E.; Doll, B. A.; Futrell, F. W.; Schmitz, J. P. \& Hollinger, J. O. Demineralized bone matrix in bone repair: history and use. Adv. Drug Deliv. Rev., 64(12):1063-77, 2012.

Huang, Z.; Cheng, C.; Wang, J.; Wei, H.; Liu, X.; Yan, X.; Zhou, Y.; Liu, Y \& Yang, S. Surface Properties and MC3T3-E1 Cell Response of Cortical Bone Allografts Modified with Low-Concentration Phosphoric Acid. Cell. Physiol. Biochem., 41(4):1572-83, 2017.

Jamjoom, A. \& Cohen, R. E. Grafts for ridge preservation. J. Funct. Biomater., 6(3):833-48, 2015. 
DIAS, F. J.; ARIAS, A.; BORIE, E.; LEZCANO, M. F.; ARELLANO - VILLALÓN, M. \& FUENTES, R. Comparison of morphological quantitative characteristics of the newly formed alveolar bone after the application of demineralized bone matrix and cortical bone allografts. Int. J. Morphol., 37(4):1509-1516, 2019.

Kadkhodazadeh, M.; Mollaverdi, F.; Abdolsamadi, H. R.; Azar, R.; Ghasemian Pour, G. \& Ahmadpour, S. Histologic effects of demineralized bone matrix on regeneration of alveolar socket in diabetic rats. Iran. Endod. J., 4(1):20-4, 2009.

Kaya, Y.; Yalim, M.; Bahçecitapar, M. \& Balos, K. Comparison of applying particulate demineralized bone matrix (DBM), putty DBM and open flap debridement in periodontal horizontal bone defects. A 12-month longitudinal, multi-center, triple-blind, split-mouth, randomized, controlled clinical study. Part 1 - clinical and radiographic evaluation. J. Oral Rehabil., 36(7):524-34, 2009.

Kremenetzky, A.; Kremenetzky, L. \& Feldman, S. Aplicación de Aloinjerto óseo como cemento biológico. Rev. Asoc. Argent. Ortop. Traumatol., 71(1):61-6, 2006

Kubota, T.; Hasuike, A.; Ozawa, Y.; Yamamoto, T.; Tsunori, K.; Yamada, Y. \& Sato, S. Regenerative capacity of augmented bone in rat calvarial guided bone augmentation model. J. Periodontal Implant Sci., 47(2):7785, 2017.

Liu, Q.; Ma, Y.; Wang, J.; Zhu, X.; Yang, Y. \& Mei, Y. Demineralized bone matrix used for direct pulp capping in rats. PLoS One, 12(3):e0172693, 2017.

Majoor, B. C.; Peeters-Boef, M. J.; van de Sande, M. A.; Appelman-Dijkstra, N. M.; Hamdy, N. A. \& Dijkstra, P. D. What is the role of allogeneic cortical strut grafts in the treatment of fibrous dysplasia of the proximal femur? Clin. Orthop. Relat. Res., 475(3):786-95, 2017.

Motamedian, S. R.; Khojaste, M. \& Khojasteh, A. Success rate of implants placed in autogenous bone blocks versus allogenic bone blocks: A systematic literature review. Ann. Maxillofac. Surg., 6(1):78-90, 2016.

Müller, M. A.; Frank, A.; Briel, M.; Valderrabano, V.; Vavken, P.; Entezari, V. \& Mehrkens, A. Substitutes of structural and non-structural autologous bone grafts in hindfoot arthrodeses and osteotomies: a systematic review. B. M. C. Musculoskelet. Disord., 14:59, 2013.

Pensak, M.; Hong, S. H.; Dukas, A.; Bayron, J.; Tinsley, B.; Jain, A.; Tang, A.; Rowe, D. \& Lieberman, J. R. Combination therapy with PTH and DBM cannot heal a critical sized murine femoral defect. J. Orthop. Res., 33(8):1242-9, 2015

Shahar, R. \& Weiner, S. Open questions on the 3D structures of collagen containing vertebrate mineralized tissues: A perspective. J. Struct. Biol., 201(3):187-98, 2018

Shalash, M. A.; Rahman, H. A.; Azim, A. A.; Neemat, A. H.; Hawary, H. E. $\&$ Nasry, S. A. Evaluation of horizontal ridge augmentation using beta tricalcium phosphate and demineralized bone matrix: A comparative study. J. Clin. Exp. Dent., 5(5):e253-9, 2013.

Yunes, M.; Sauri-Esquivel, E. A.; Carrillo-Ávila, B. A.; Martínez-Aguilar, V. M. \& Castillo-Bolio, R. Autoinjerto en bloque como tratamiento de colapso alveolar en maxilar superior. Rev. Odontol. Latinoam., 7(2):6570,2015 .
Corresponding author:

Prof. Dr. Ramón Fuentes Fernández

Dental School, Universidad de La Frontera

Av. Francisco Salazar 01145, 4781176

Temuco

CHILE

Email: ramon.fuentes@ufrontera.cl

Received: 23-01-2019

Accepted: 05-06-2019 